\title{
The effect of lake restoration by the hypolimnetic withdrawal method on the intensity of ambient odour
}

\author{
Renata TANDYRAK,${ }^{1 *}$ Iwona GOŁAŚ,,${ }^{2}$ Katarzyna PARSZUTO, ${ }^{1}$ Magdalena BOWSZYS, ${ }^{3}$ Daniel SZYMAŃSKI, ${ }^{1}$ \\ Monika HARNISZ, ${ }^{2}$ Andrzej BRUDNIAK, ${ }^{4}$ Izabela WYSOCKA ${ }^{4}$ \\ ${ }^{1}$ Department of Water Protection Engineering, University of Warmia and Mazury, Prawocheńskiego 1, 10-957 Olsztyn; ${ }^{2}$ Department \\ of Environmental Microbiology, University of Warmia and Mazury, Prawocheńskiego 1, 10-957 Olsztyn; ${ }^{3}$ Department of Tourism, \\ Recreation and Ecology, University of Warmia and Mazury, Oczapowskiego 5, 10-957 Olsztyn; ${ }^{4}$ Department of Environmental \\ Engineering, University of Warmia and Mazury, Warszawska 117, 10-957 Olsztyn, Poland \\ *Corresponding author: renatat@uwm.edu.pl
}

\begin{abstract}
The objective of this study was to evaluate the effect of lake restoration by the hypolimnetic withdrawal method on the intensity of ambient odour in the vicinity of the pipeline outlet. The study was carried out in 2012-2013 from the beginning of the summer stagnation period in Lake Kortowskie to complete overturn in fall. Samples of river water and ambient air were collected from two sites: near the pipeline outlet (PO) and behind the academic campus (AC). A total of 44 air samples and 44 water samples were analysed. Odour intensity was measured in samples of ambient air. The following physicochemical parameters of water were determined: flow rate, dissolved oxygen $(\mathrm{DO})$, hydrogen sulphide $\left(\mathrm{H}_{2} \mathrm{~S}\right)$, sulphate $\left(\mathrm{SO}_{4}\right)$, ammonium nitrogen $\left(\mathrm{NH}_{4}-\mathrm{N}\right)$, total nitrogen $(\mathrm{TN})$, dissolved nitrogen $(D N)$, total particulate nitrogen (T-PN), total organic carbon (TOC), dissolved organic carbon (DOC) and total particulate organic carbon (T-POC). Water samples were also analysed to determine total bacterial abundance (TBA) and the counts of bacterial rods, cocci and spiral-shaped bacteria, and sulphate-reducing bacteria (SRB). Significant variations in odour intensity were noted between years and sampling sites. Odour was significantly determined by the proportion of lake water in river water. It was also significantly correlated $(P<0.01, P<0.001)$ with most of the analysed physicochemical and microbiological parameters. The multiple regression analysis revealed that odour intensity was influenced directly by TOC and DN and indirectly by $\mathrm{H}_{2} \mathrm{~S}, \mathrm{NH}_{4}-\mathrm{N}, \mathrm{TBA}$ and counts of SRB, rod-and spiral-shaped bacteria only in.
\end{abstract}

Key words: Hypolimnetic withdrawal; odour; TOC; $\mathrm{H}_{2} \mathrm{~S} ; \mathrm{N}-\mathrm{NH}_{4}$; bacteria.

Received: December 2015. Accepted: May 2016.

\section{INTRODUCTION}

Eutrophication has become the primary water quality problem for most of the freshwater ecosystems in the world. It is one of the most visible examples of biosphere's alteration due to human activities affecting aquatic ecosystems (Zamparas and Zacharias, 2014). One of the lake restoration method is a hypolimnetic withdrawal that has gained popularity over the years and is presently used to restore optimal water conditions in around 40 European lakes and 8 North American lakes (Nürnberg, 2007; Lehman et al., 2009).

Moreover, the hypolimnetic withdrawal method is suitable for lakes that are stratified over summer and become anoxic in the layer of hypolimnion. A recognized disadvantage of this restoration technique is its impact on downstream waters, including eutrophication, oxygen depletion and odour development (Nürnberg, 2007). This method involves the removal of oxygen-deficient water from the lake's hypolimnion layer, which is characterized by significant fertility and the presence of methane, hydrogen sulphide and decomposable organic matter, to the receiv- ing body, usually a river (Cooke et al., 1982; Klapper, 1991; Nürnberg, 2007; Górniak et al., 2014; Zamparas and Zacharias, 2014). Hypolimnion water pollutes the watercourse into which it is discharged, and it induces periodic changes in hydrochemical and biological conditions (Elloumi et al., 2008). Some previous studied showed that without careful management, hypolimnetic releases can degrade water quality in the receivers such as rivers with small flows (Marshall et al., 2006; Nürnberg, 2007). An additional side effect that is often disregarded by lake restoration studies is the characteristic and unpleasant odour of hydrogen sulphide in the surrounding air. This is a consequence of hydrogen sulphide presence, which is produced in the hypolimnion by microbiological processes of decomposition of sulphur-containing organic matter or by dissimilatory sulphate reduction (Ito et al., 2002).

Most restoration programs involve lakes in urban areas (Klapper, 1991; Cooke et al., 1993), therefore, odour poses a serious nuisance for local inhabitants and recreational lake users. Odour associated with surface waters and their surroundings has attracted the interest of re- 
searchers in recent decades (Azkona et al., 1984; Wnorowski, 1992, Yongsiri et al., 2004; Brudniak et al., 2013). Unpleasant odour poses a significant problem for households which must be supplied with odourless and neutrally tasting potable water as well as for regions where water bodies are used for recreational purposes. Selected water odours have natural origin and may be associated with high concentrations of dissolved minerals. Yet most odours result from human activity and the evacuation of household, agricultural and industrial effluents which speed up the eutrophication of water bodies (Wnorowski, 1992; Huu Huan et al., 2013). Growing pollution levels in water bodies, in particular lakes require urgent measures to inhibit and reverse those processes, including as part of restoration programs (Cooke et al., 1982; Klapper, 1991).

The researchers are focused on the positive effects of the hypolimnetic withdrawal but only for the recultivated reservoirs (Marshall et al., 2006; Nürnberg, 2007; Lehman et al., 2009; Dunalska et al., 2012, 2013). We think that our studies are unique worldwide because we did not found any papers, which were interesting in the effect of this method on the surrounding environment, e.g. rivers and air. Therefore an idea of our study could be important for reservoirs restored by the hypolimnetic withdrawal method in another places in the world.

Unpleasant odour is a symptom of pollution that exerts a highly negative influence on both the natural environment and human settlements (Kośmider et al., 2002; WHO, 2003). This is the case in Lake Kortowskie (NE Poland) where restoration measures have been carried out continuously since the 1956. Selective discharge of bottom water is accompanied by the formation of unpleasant odour that is highly annoying for 30,000 inhabitants of the surrounding residential districts as well as numerous tourists. This study was undertaken to determine whether and to what extent the chemical and microbiological composition of hypolimnetic water evacuated from Lake Kortowskie influences the intensity of odorous emissions.

\section{METHODS}

\section{Study area and collection of samples}

The restoration program in Lake Kortowskie $\left(53^{\circ} 45^{\prime} 42.6^{\prime} \mathrm{N} 20^{\circ} 26^{\prime} 41.9^{\prime}\right.$ 'E) has continued since 1956, and it involves selective discharge of bottom water. The pipeline evacuating hypolimnetic water is situated in the southern part of the lake, and its inlet is found in the deepest point of the lake at a depth of $17.2 \mathrm{~m}$. Bottom water is discharged by the pipeline to the Kortówka River which flows out of the lake in the south-west (Fig. 1). Together with hypolimnion water the settling organic particles and products of their degradation are removed from the lake, as well as the substances and microorganisms released from the bottom sediments. The lake restoration method and the outcomes of this long-term project have been discussed by Dunalska (2003) and Dunalska et al. (2007). Hypolimnetic withdrawal via the pipeline begins during thermal stratification (water stagnation) in early July and ends with the onset of the fall turnover in late October. The lake is situated in the immediate vicinity of large residential districts of Słoneczny Stok and Kortowo as well as the academic campus. Lake Kortowskie is also a popular recreational site and tourist destination in summer. Samples of water and air were collected in two sites: site $\mathrm{PO}$, at an estimated distance of $2 \mathrm{~m}$ from the outlet of the pipeline discharging water from Lake Kortowskie to the Kortówka River; site AC, behind the academic campus, at an estimated distance of $0.5 \mathrm{~km}$ from PO (Fig. 1). Samples of water and ambient air were collected simultaneously between July and October 2012-2013, every 10 days on average. A total of 88 samples were collected, including 44 water and 44 air samples.

Air samples were collected by the lung method with the use of gas cylinders with a battery-powered fan into pre-conditioned Tedler bag inside the cylinder. Water samples for physicochemical and microbiological analyses were collected at the centre of the main river flow at a depth of 20-30 cm. Detailed diagram of physicochemical and microbiological analyses was illustrated in Fig. 2.

\section{Air sample analysis}

Air samples were analysed ex situ by dynamic olfactometry. Odour concentrations were determined in the yes/no mode by trained panellists, with the use of the Ecoma Olfactometer TO 8. Olfactory sensitivity in panellists was regularly controlled and verified with a standard odorant, n-butanol. The analysis was conducted in accordance with European standard EN 13725:2003 (http://www.en-standard.eu/).

\section{Physicochemical analyses of water samples}

Water flow rates in the river and the pipeline were measured with the Valeport 801 flow meter according to the method described by Bajkiewicz-Grabowska et al. (1987). The percentage proportions of lake water in river water were calculated based on flow measurements. Dissolved oxygen (DO) concentrations were determined by the Winkler's method, hydrogen sulphide $\left(\mathrm{H}_{2} \mathrm{~S}\right)$ levels - by iodometric titration, sulphate $\left(\mathrm{SO}_{4}\right)$ concentrations were measured in the Dionex-Hach ICS 3000 system, and ammonium nitrogen $\left(\mathrm{NH}_{4}-\mathrm{N}\right)$ levels - in the Merck SQ118 photometer. For organic carbon fractions, particulate organic carbon (POC) and dissolved organic carbon (DOC) were separated by filtration through a membrane with 0.45 $\mu \mathrm{m}$ pore size (Sartorius). Each filter was washed with 200 $\mathrm{mL}$ of deionized water. To determine the content of organic 


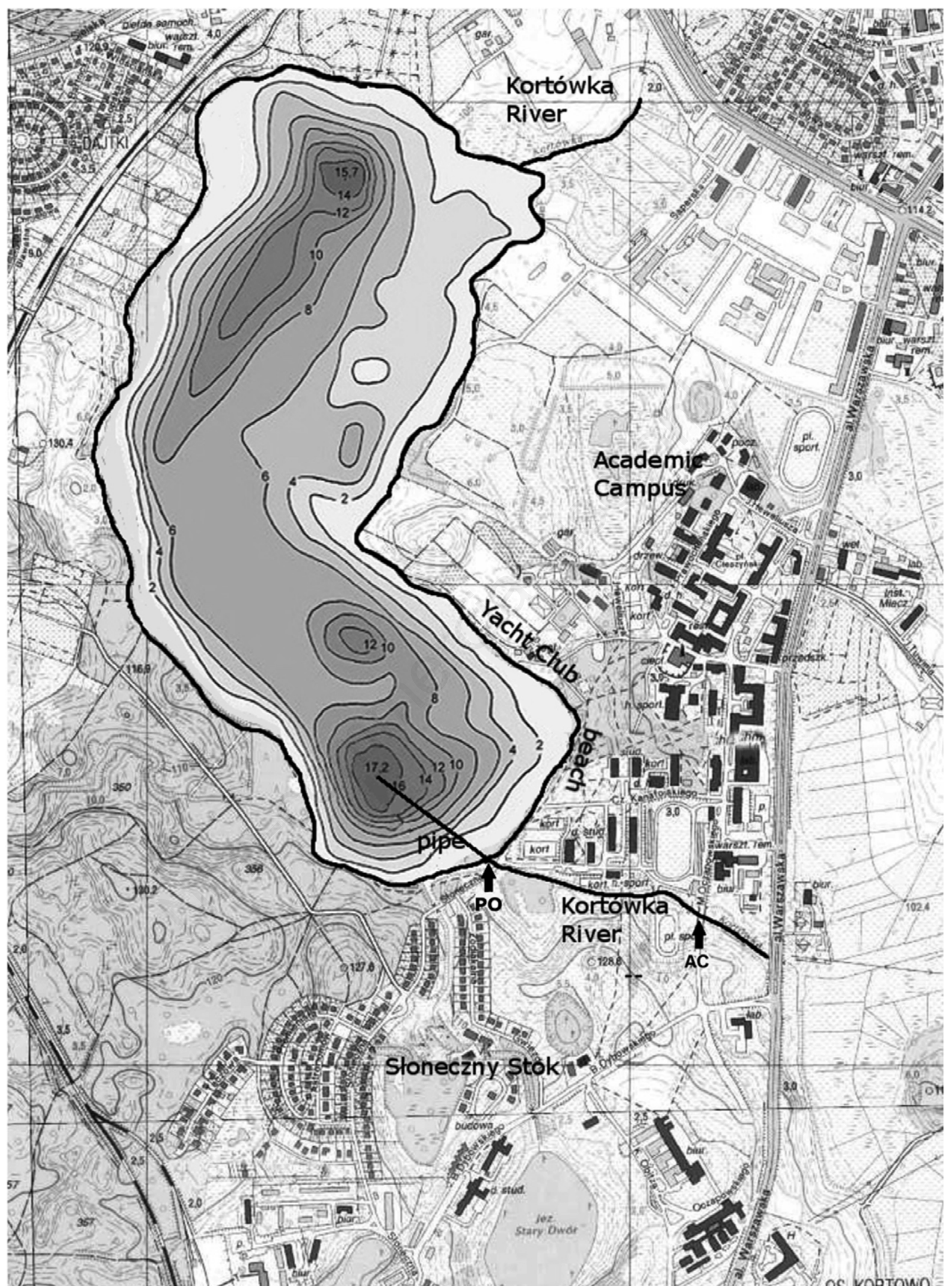

Fig. 1. Location of sampling sities (PO, AC) in the Kortówka River. A map of a part of Olsztyn showing Kortowskie Lake and the pipeline, Kortówka River and residential districts of Słoneczny Stok and Kortowo as well as the academic campus. 
carbon, a sample was acidified to $\mathrm{pH} 2$ with $4 \mathrm{M} \mathrm{HCl}$, and inorganic carbon forms were removed by passing oxygen through the sample. The concentrations of non-volatile total organic carbon (TOC) and dissolved organic carbon (DOC) were determined by the HACH IL 550 TOC-TN analyser, and total particulate organic carbon (T-POC) content was calculated as the difference in organic carbon concentrations in filtered and non-filtered samples (T-POC $=$ TOCDOC) according to Norm PN-EN 1484:1999.

The content of total nitrogen (TN) and total dissolved nitrogen (DN, in filtrate passed through a membrane with $0.45 \mu \mathrm{m}$ pore size) was determined after mineralization $\left(850^{\circ} \mathrm{C}\right)$ in a chemiluminescence detector as nitrogen oxides (HACH IL 550 TOC-TN analyser). Total nitrogen in suspension (T-PN) was calculated as: T-PN=TN-DN.

\section{Determination of total bacterial counts (DAPI staining) and in situ hybridization (FISH)}

The samples for the quantification of bacterial communities by the FISH method and DAPI staining were fixed according to the protocol described by GotkowskaPłachta et al. (2016) and Loy et al. (2007). Total bacterial abundance (TBA) and percentages of different morphological forms were determined by epifluorescence microscopy (Porter and Feig, 1980). Triplicate subsamples were fixed with neutralized formaldehyde $(\mathrm{pH} 7.4$, final concentration 4\%) and stained with DAPI (SigmaAldrich, St. Louis, MO, USA) with a final concentration of $0.01 \mathrm{ng} \mathrm{mL}{ }^{-1}$ for $15 \mathrm{~min}$ in the dark. The samples were gently passed through black Nuclepore filters with $0.2 \mu \mathrm{m}$ pore size (GTTP, Millipore). Bacteria were counted under an Olympus epifluorescence microscope. More than 1000 bacterial cells were counted in 20 fields of view. Morphological differences between bacteria were identified based on the size and shape of bacterial cells according to the method described by Ruusuvuori et al. (2008) and Hiremath and Bannigidad (2012).

The analysis of sulphate-reducing bacteria (SRB) populations was performed with Cy3-labeled probes focusing on sulphate-reducing bacteria (SRB) of the families Desulfovibrionaceae (probe SRB385) (Amann et al., 1990) and Desulfobacteriaceae (probe SRB385Db) (Rabus et al., 1996). For the hybridization process, $2 \mu \mathrm{L}\left(50 \mathrm{ng} \mu \mathrm{L}^{-1}\right)$ of SRB385 and SRB385Db probe solution was combined with $18 \mu \mathrm{L}$ of the hybridization buffer containing $1 \mathrm{mM}$ Tris $\mathrm{HCl} \mathrm{pH} \mathrm{7.4,} 5 \mathrm{M} \mathrm{NaCl}, 10 \%$ SDS, and formamide. Formamide concentrations varied subject to the applied probe $(20 \%$ for SRB and $30 \%$ for SRB $385 \mathrm{Db})$. The prepared solution $(20 \mu \mathrm{L})$ was applied to filter pieces and hybridized at $46-50^{\circ} \mathrm{C}$ for $1.5-3 \mathrm{~h}$, subject to the applied probe. The probe was cleaned with a warm rinse buffer $\left(46^{\circ} \mathrm{C}\right)$ whose composition was identical to that of the hybridization buffer with the exception of formamide, which was replaced with 0.5MEDTA, pH 8 (Manz et al., 1998, Tonolla et al., 2000). Filters were rinsed with ultrapure water; they were dried and stained with the DAPI solution $(50 \mu \mathrm{L})$ for $3 \mathrm{~min}$ at room temperature in dark. Stained fil-

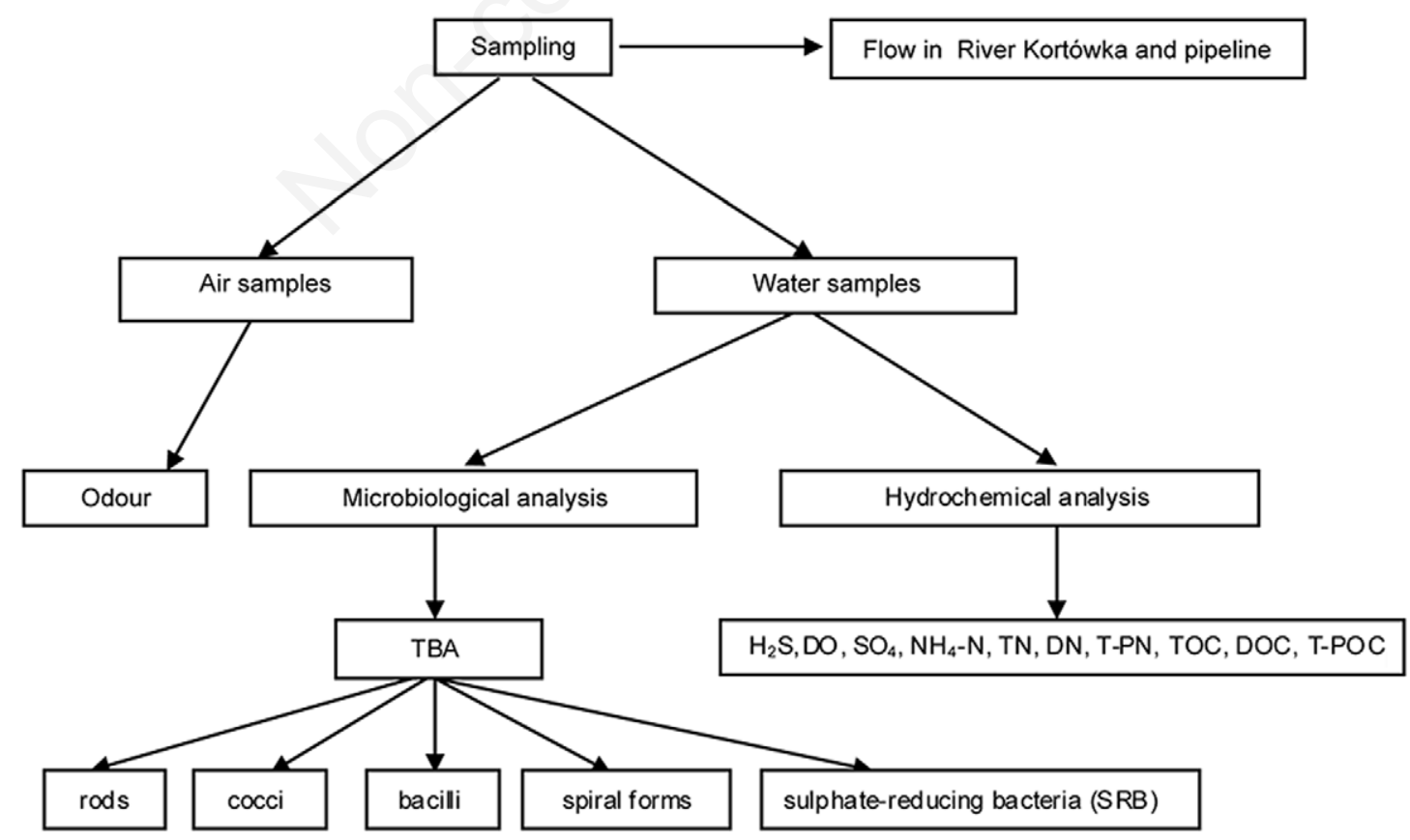

Fig. 2. Detailed diagram of physicochemical and microbiological analyses. 
ters were thoroughly rinsed with $80 \%$ ethanol for more than $10 \mathrm{~s}$ to remove non-specific bonds; after which, they were rinsed with sterile distilled water and dried in air. Filter pieces were attached to slides with Citifluor (Agar Scientific, Essex, UK) and Vectashield (Vector Laboratories, Burlingame, CA, USA) immersion oils, applied 4:1, and covered with coverslips. The sulphate-reducing bacteria (SRB) was viewed under a fluorescent microscope (Olympus BX61) equipped with a $\times 100$ oil immersion lens, UV lamp, DAPI and CY3 filters, and a CCD camera (Olympus). Images were analysed in the Cell $\mathrm{F}$ application (Olympus). More than 100 hybridized bacterial cells (FISH) and 1000 to 10,000 DAPI-stained bacterial cells were identified per every evaluated sample. Mean values and standard deviation were calculated from 20 random fields of view in every filter section and expressed in terms of $1 \mathrm{~mL}$ of water. The signal obtained with probe NON338 - a negative control - at each samples was subtracted from the specific counts. This signal was about $0.5 \%$ of the cell counts for each samples. The numbers of sulphate-reducing bacteria (SRB) were determined as the sum of cells hybridizing to probes SRB385Db targeting Desulfobacteriaceae and SRB385 targeting Desulfovibrionaceae. Mean values and standard deviation of TBA, SRB, rods, bacilli, cocci and spiral forms were expressed in terms of $1 \mathrm{~mL}$ of water. Additionally, the SRB, rods, bacilli, cocci and spiral forms counts were presented as the number and percentage of cells visualized by DAPI.

\section{Statistical analysis}

The significance of differences in the physicochemical parameters and bacterial counts in water and air samples from the Kortówka River between sampling seasons were determined by one-way analysis of variance (ANOVA). Leven's test was used to assess the homogeneity of variance. When Leven's test produced statistically significant results, the verified hypothesis was rejected. The KruskalWallis test, a non-parametric version of classical one-way ANOVA (Stanisz, 2006), was then applied. The correlations between the physicochemical parameters and bacterial counts in water and air samples were determined by Spearman's non-parametric rank correlation test $(\mathrm{P}<0.05$, $\mathrm{P}<0.01, \mathrm{P}<0.001)$ and multiple regression. Statistical analyses were performed in the Statistica 10.0 (StatSoft, Poland).

\section{RESULTS}

\section{Physicochemical analyses of air and water samples}

The mean values and standard deviations of physicochemical and microbiological parameters of water and air samples are presented in Tab. 1. Statistically significant

Tab. 1. Mean an standard deviation $( \pm \mathrm{SD})$ values of physicochemical and microbiological parameters in air and water samples collected at River Kortówka in the years 2012-2013.

\begin{tabular}{|c|c|c|c|c|c|c|}
\hline \multirow[t]{2}{*}{ Parameter } & \multicolumn{2}{|c|}{ Site PO } & \multicolumn{2}{|c|}{ Site $\mathbf{A C}$} & \multicolumn{2}{|c|}{ Differences $(\mathrm{P})$ between: } \\
\hline & 2012 & 2013 & 2012 & 2013 & Years & Sampling sites \\
\hline $\operatorname{Odour}\left(\mathrm{o}_{\mu \varepsilon} \mathrm{m}^{-3}\right)$ & $1229 \pm 1599$ & $33.6 \pm 17.31$ & $32.36 \pm 16.88$ & $0.02 \pm 0.01$ & $0.0000^{* * *}$ & $0.0206^{*}$ \\
\hline Flow in the river $\left(\mathrm{L} \mathrm{s}^{-1}\right)$ & $63.61 \pm 11.02$ & $62.26 \pm 11.55$ & $55.60 \pm 10.84$ & $58.15 \pm 10.12$ & 0.8182 & 0.6543 \\
\hline Flow in the pipeline $\left(\mathrm{L} \mathrm{s}^{-1}\right)$ & $37.78 \pm 8.26$ & $31.19 \pm 19.12$ & na & na & 0.1783 & na \\
\hline $\mathrm{H}_{2} \mathrm{~S}\left(\mathrm{mg} \mathrm{S}^{-2} \mathrm{~L}^{-1}\right)$ & $3.73 \pm 0.78$ & $1.05 \pm 0.47$ & $1.01 \pm 0.46$ & $0.13 \pm 0.06$ & $0.0000^{* * *}$ & $0.0207^{*}$ \\
\hline $\mathrm{DO}\left(\mathrm{mg} \mathrm{L}^{-1}\right)$ & $1.80 \pm 0.51$ & $5.15 \pm 2.73$ & $5.34 \pm 2.65$ & $3.67 \pm 1.70$ & 0.0887 & 0.075 \\
\hline $\mathrm{SO}_{4}\left(\mathrm{mg} \mathrm{L}^{-1}\right)$ & $17.15 \pm 1.58$ & $21.17 \pm 4.05$ & $21.17 \pm 4.05$ & $18.12 \pm 1.96$ & 0.5261 & 0.1127 \\
\hline TOC $\left(\mathrm{mg} \mathrm{L}^{-1}\right)$ & $14.83 \pm 1.68$ & $10.92 \pm 1.22$ & $13.57 \pm 1.10$ & $10.42 \pm 1.21$ & $0.0022^{*}$ & 0.2802 \\
\hline $\mathrm{DOC}\left(\mathrm{mg} \mathrm{L}^{-1}\right)$ & $11.47 \pm 1.57$ & $8.31 \pm 0.96$ & $10.51 \pm 1.50$ & $7.67 \pm 0.88$ & 0.0650 & 0.1590 \\
\hline T-POC $\left(\mathrm{mg} \mathrm{L}^{-1}\right)$ & $3.37 \pm 1.29$ & $2.62 \pm 0.86$ & $3.06 \pm 1.00$ & $2.75 \pm 1.15$ & 0.3358 & 0.8973 \\
\hline $\mathrm{NH}_{4}-\mathrm{N}\left(\mathrm{mg} \mathrm{N} \mathrm{L}^{-1}\right)$ & $1.16 \pm 0.41$ & $0.43 \pm 0.20$ & $0.41 \pm 0.20$ & $0.56 \pm 0.28$ & $0.0477^{*}$ & $0.0253^{*}$ \\
\hline $\mathrm{TN}\left(\mathrm{mg} \mathrm{L}^{-1}\right)$ & $4.36 \pm 0.88$ & $1.99 \pm 0.44$ & $1.38 \pm 0.15$ & $1.56 \pm 0.13$ & $0.0433^{*}$ & $0.0206^{*}$ \\
\hline $\mathrm{DN}\left(\mathrm{mg} \mathrm{L}^{-1}\right)$ & $3.56 \pm 0.83$ & $0.96 \pm 0.33$ & $0.97 \pm 0.31$ & $1.16 \pm 0.16$ & $0.0171^{*}$ & $0.0207^{*}$ \\
\hline T-PN $\left(\mathrm{mg} \mathrm{L}^{-1}\right)$ & $1.12 \pm 0.48$ & $0.99 \pm 0.32$ & $0.41 \pm 0.20$ & $0.40 \pm 0.10$ & 0.3657 & 0.2282 \\
\hline TBA $\left(\times 10^{6}\right.$ cell $\left.\mathrm{mL}^{-1}\right)$ & $22.08 \pm 7.86$ & $12.37 \pm 6.77$ & $8.82 \pm 4.38$ & $6.81 \pm 3.37$ & $0.0015^{* *}$ & $0.0067^{* *}$ \\
\hline Rods $\left(\times 10^{6}\right.$ cell $\left.\mathrm{mL}^{-1}\right)$ & $11.77 \pm 5.12$ & $5.99 \pm 3.75$ & $2.29 \pm 1.41$ & $1.31 \pm 1.09$ & $0.0484^{*}$ & $0.0002^{* * *}$ \\
\hline $\operatorname{Cocci}\left(\times 10^{6}\right.$ cell $\left.\mathrm{mL}^{-1}\right)$ & $6.01 \pm 3.06$ & $5.01 \pm 2.60$ & $5.52 \pm 2.60$ & $4.30 \pm 1.98$ & 0.1156 & 0.3395 \\
\hline Bacilli $\left(\times 10^{6}\right.$ cell $\left.\mathrm{mL}^{-1}\right)$ & $1.06 \pm 0.59$ & $0.91 \pm 0.77$ & $0.88 \pm 0.43$ & $0.58 \pm 0.34$ & 0.1456 & 0.8486 \\
\hline Spiral forms $\left(\times 10^{6}\right.$ cell $\left.\mathrm{mL}^{-1}\right)$ & $2.98 \pm 1.31$ & $0.19 \pm 0.11$ & $0.23 \pm 0.14$ & $0.18 \pm 0.09$ & $0.0005^{* * *}$ & $0.0457^{*}$ \\
\hline $\operatorname{SRB}\left(\times 10^{6}\right.$ cell $\left.\mathrm{mL}^{-1}\right)$ & $7.51 \pm 1.52$ & $1.53 \pm 0.96$ & $0.65 \pm 0.38$ & $0.24 \pm 0.14$ & $0.0060^{* *}$ & $0.0054^{* *}$ \\
\hline
\end{tabular}

$D O$, dissolved oxygen; $T N$, total nitrogen; $D N$, dissolved nitrogen; T-PN, total particular nitrogen; TOC, total organic carbon; DOC, dissolved organic carbon; T-POC, total particular organic carbon; TBA, total bacterial abundance; SRB, sulphate-reducing bacteria; na, not applicable; ${ }^{*} P<0.05$; $\left.{ }^{* *} P<0.01\right) ;{ }^{* * *} P<0.001$. 
differences $(\mathrm{P}<0.05, \mathrm{P}<0.01, \mathrm{P}<0.001)$ were noted in odour intensity, the concentrations of $\mathrm{H}_{2} \mathrm{~S}, \mathrm{TOC}, \mathrm{NH}_{4}-\mathrm{N}$, TN and DN, TBA.

In sampling site $\mathrm{PO}$, odour intensity was determined at 91-5161 o $\mu_{\varepsilon} \mathrm{m}^{-3}$ in 2012 and 12-64 o $\mu_{\varepsilon} \mathrm{m}^{-3}$ in 2013. The highest odour intensity was observed at the peak of summer stagnation and at the beginning of the fall turnover period in both years of the study. The values of the above parameters decreased gradually in fall. In sampling site AC, odour intensity in 2012 was significantly (2- to 24-fold) lower than in site PO. In 2013, odour was generally not detected in $\mathrm{AC}$, whereas in $\mathrm{PO}$, its values did not exceed several dozen $\mu_{\varepsilon} \mathrm{m}^{-3}$ (Fig. $3 \mathrm{a}, \mathrm{b}$ ).

In 2012, $\mathrm{H}_{2} \mathrm{~S}$ concentrations in $\mathrm{PO}$ were determined in the range of 2.58-4.84 $\mathrm{mg} \mathrm{S}^{-2} \mathrm{~L}^{-1}$ whereas in $2013, \mathrm{H}_{2} \mathrm{~S}$ levels were significantly lower at $0.50-1.87 \mathrm{mg} \mathrm{S}^{-2} \mathrm{~L}^{-1}$. In water samples collected from $\mathrm{PO}, \mathrm{H}_{2} \mathrm{~S}$ concentrations decreased gradually in both periods of the study, beginning from the peak of summer stagnation (late August). In water samples from sampling site $\mathrm{AC}, \mathrm{H}_{2} \mathrm{~S}$ concentrations were lower in both years of the study: they did not exceed 1.5 $\mathrm{mg} \mathrm{S}^{-2} \mathrm{~L}^{-1}$ in 2012 , and they were sporadically detected in amounts not higher than $0.5 \mathrm{mg} \mathrm{S}^{-2} \mathrm{~L}^{-1}$ in 2013. In both years, $\mathrm{H}_{2} \mathrm{~S}$ levels decreased significantly $(\mathrm{P}<0.05)$ down the river. In samples from both sites and both years, the lowest concentrations of $\mathrm{H}_{2} \mathrm{~S}$ were accompanied by the highest levels of DO (Fig. 3 a,b) and the two parameters were significantly inversely correlated $(\mathrm{P}<0.01)$
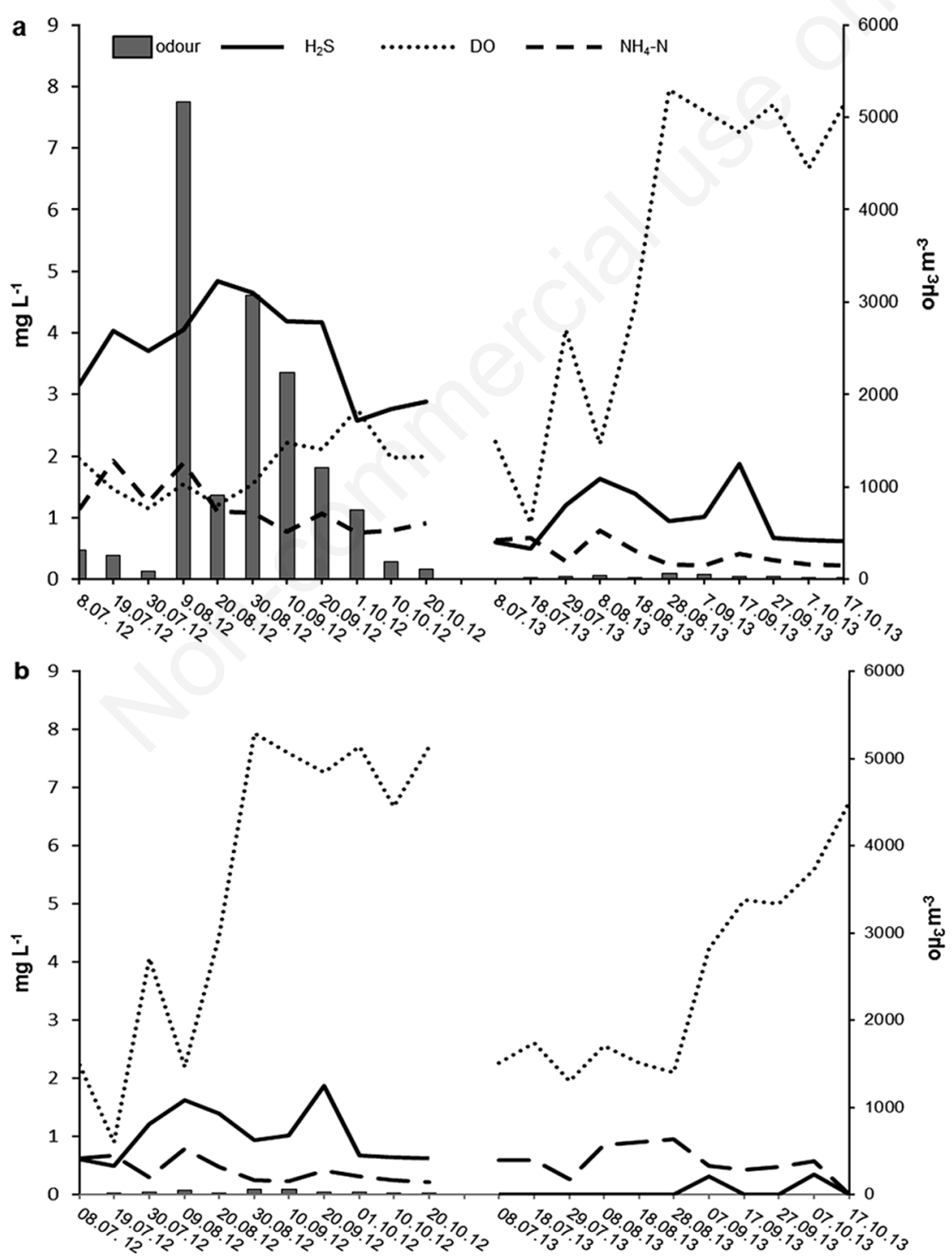

Fig. 3. Changes in the intensity of ambient odour and concentrations of $\mathrm{H}_{2} \mathrm{~S}, \mathrm{DO}$ and $\mathrm{NH}_{4}-\mathrm{N}$ in water samples collected from sites $\mathrm{PO}$ (a) and AC (b) in 2012 and 2013. 
(Tab. 2). The concentrations of $\mathrm{NH}_{4}-\mathrm{N}$ varied significantly $(\mathrm{P}<0.05)$ between years and sampling sites. They were determined at $0.76-1.93 \mathrm{mg} \mathrm{N} \mathrm{L}^{-1}$ in 2012 and $0.23-0.79 \mathrm{mg}$ $\mathrm{N} \mathrm{L}^{-1}$ in 2013 in $\mathrm{PO}$ samples and at $0.62-1.61 \mathrm{mg} \mathrm{N} \mathrm{L}^{-1}$ in 2012 and $0.00-0.96 \mathrm{mg} \mathrm{N} \mathrm{L}^{-1}$ in AC samples. In samples from both sites, $\mathrm{NH}_{4}-\mathrm{N}$ accounted for $21-22 \%$ of TN. In both years of the study, $\mathrm{NH}_{4}-\mathrm{N}$ levels, similarly to odour intensity and $\mathrm{H}_{2} \mathrm{~S}$, were highest during summer stagnation (July to August) and lowest in the fall turnover period (October) (Fig. 3 a,b). Dissolved nitrogen was the predominant form of $\mathrm{N}$ in water samples from both sites, and its average percentage proportions in $\mathrm{TN}$ reached $85 \%$ in 2012 and $69 \%$ in 2013. High TN and DN values were noted between July and August 2012, and a significant decrease in those parameters in river water was observed at the beginning of fall turnover in the lake. The above trend was not noted in 2013 when TN and DN values were significantly lower in both sampling sites. Total particulate nitrogen (T-PN) levels were higher in PO samples than in AC samples in both years of the study. In PO, maximum T-PN values were observed at the beginning of the fall turnover period in the lake at $1.83 \mathrm{mg} \mathrm{N} \mathrm{L}^{-1}$ in 2012 and $1.31 \mathrm{mg} \mathrm{N} \mathrm{L}^{-1}$ in 2013. In $\mathrm{AC}$, no significant changes in T-PN were noted during the study (Fig. 4 a,b). Those trends were verified by the statistical analysis which revealed significant differences $(\mathrm{P}<0.05)$ in the concentrations of $\mathrm{TN}$ and $\mathrm{DN}$ between years and sampling sites (Tab. 1). In PO, TOC levels were determined in the range of $12.40-16.50 \mathrm{mg} \mathrm{C} \mathrm{L}^{-1}$ in 2012 and 9.55-12.92 $\mathrm{mg} \mathrm{C} \mathrm{L}^{-1}$ in 2013. The average DOC concentrations reached $11.47 \pm 1.57 \mathrm{mg} \mathrm{L}^{-1}$ in 2012 and $8.31 \pm 0.96 \mathrm{mg} \mathrm{L}^{-1}$ in 2013 . In both years of the study, DOC values tended to increase between July and October. In water samples collected from AC, TOC concentrations were approximately $20-30 \%$ lower in comparison with PO samples and were determined at 9.43-15.42 $\mathrm{mg} \mathrm{C} \mathrm{L}^{-1}$ with a similar percentage of DOC (63-92\%) (Fig. 5 a,b). In PO samples, T-POC levels were significantly lower than DOC concentrations at $3.37 \mathrm{mg} \mathrm{L}^{-1}$ in 2012 and $2.62 \mathrm{mg} \mathrm{L}^{-1}$ in 2013 on average. The statistical analysis revealed variations only in TOC concentrations between the years (Tab. 1).

Direct and indirect correlations were found between odour intensity and the analysed physicochemical parameters of water only in sampling site PO. Highly significant correlations $(\mathrm{P}<0.01, \mathrm{P}<0.001)$ were determined between odour intensity and the concentrations of $\mathrm{H}_{2} \mathrm{~S}, \mathrm{TN}, \mathrm{DN}, \mathrm{T}-$ $\mathrm{PN}$ and TOC. Odour intensity was significantly correlated $(\mathrm{P}<0.05)$ with the percentage of lake water in river water and with $\mathrm{NH}_{4}-\mathrm{N}$ levels (Tab. 2). The multiple regression analysis revealed that odour intensity was directly correlated with the concentrations of TOC and DN ( $r=0.4959$, $\mathrm{P}<0.0014)$. Odour intensity was indirectly correlated with $\mathrm{H}_{2} \mathrm{~S}$ and $\mathrm{NH}_{4}-\mathrm{N}$ values $(\mathrm{r}=0.73052, \mathrm{P}<0.0012)$.

\section{Abundance of bacterial communities}

Total bacterial abundance ranged from $10^{4}$ to $10^{7}$ cells $\mathrm{mL}^{-1}$, subject to bacterial group, sampling site and sampling date. The variations in bacterial counts were validated by the statistical analysis which revealed significant differences $(\mathrm{P}<0.05, \mathrm{P}<0.01, \mathrm{P}<0.001)$ in TBA values and counts of SRB, rod- and spiral-shaped bacteria between sampling sites and years (Tab. 1). In 2013, water samples collected

Tab. 2. Statistic estimation by Spearman's correlation between physicochemical parameters and numbers of studied microorganisms recovered from the air and water samples collected at River Kortówka.

\begin{tabular}{|c|c|c|c|c|c|c|c|c|c|c|c|}
\hline & Odour & DO & $\mathrm{H}_{2} \mathrm{~S}$ & $\mathrm{SO}_{4}$ & $\mathrm{NH}_{4}-\mathrm{N}$ & TN & DN & T-PN & TOC & DOC & T-POC \\
\hline$\%$ of lake water in river water & $0.487^{*}$ & $-0.741^{* *}$ & $0.540^{* *}$ & $-0.827^{* * *}$ & $0.773^{* * *}$ & $0740^{* * *}$ & $0691^{* * *}$ & $0.574^{* *}$ & & & \\
\hline Odour & & & $0.946^{* * *}$ & & $0.358^{*}$ & $0.427^{* *}$ & $0.425^{* *}$ & $0.393^{* *}$ & & & \\
\hline $\mathrm{DO}$ & & & $-0.414^{* *}$ & $0.806^{* * *}$ & $-0.833^{* * *}$ & $-0.710^{* * *}$ & $-0.773^{* * *}$ & & & & \\
\hline $\mathrm{H}_{2} \mathrm{~S}$ & & & & & $0.445^{* *}$ & $0.441^{* *}$ & $0.478^{* * *}$ & $0.371^{*}$ & & & \\
\hline $\mathrm{SO}_{4}$ & & & & & $-0.749^{* * *}$ & $-0.718^{* * *}$ & $-0.658^{* * *}$ & $-0.387^{* *}$ & & & \\
\hline $\mathrm{NH}_{4}-\mathrm{N}$ & & & $0.384^{*}$ & & & $0.820^{* * *}$ & $0.836^{* * *}$ & $0.338^{* *}$ & & & \\
\hline $\mathrm{TN}$ & & & & & & & $0.863^{* * *}$ & $0.593^{* * *}$ & & & \\
\hline TOC & & $0.880^{* * *}$ & $0.775^{* * *}$ & $0,555^{* *}$ & $0,519^{*}$ & & & $0.807^{* * *}$ & & $0.880^{* * *}$ & $0.77^{* * *}$ \\
\hline $\mathrm{DOC}$ & & & $0.413^{* *}$ & $0,654^{* * *}$ & $0,631^{* *}$ & & & & & & $0.413^{* *}$ \\
\hline \multicolumn{12}{|l|}{ T-POC } \\
\hline TBA & $0.545^{* * *}$ & $-0.586^{* * *}$ & $0.553^{* * *}$ & $-0.506^{* * *}$ & $0.554^{* * *}$ & $0.518^{* * *}$ & $-0.720^{*}$ & $0.793^{* * *}$ & $0.555^{* *}$ & $0.654^{* * *}$ & \\
\hline Rods & $0.639^{* * *}$ & $-0.536^{* * *}$ & $0.628^{* * *}$ & $-0.454^{* *}$ & $0.518^{* * *}$ & $0.495^{* * *}$ & $-0.642^{*}$ & $0.756^{* * *}$ & $0.519^{*}$ & $0.631^{* * *}$ & \\
\hline Bacilli & & & & & & & & $0.512^{* * *}$ & & & \\
\hline Cocci & & $0.376^{*}$ & & & & & & $0.528^{* * *}$ & & & \\
\hline Spiral forms & $0.595^{* * *}$ & & & & & & & & & & \\
\hline SRB & $0.762^{* * *}$ & $-0.503^{* * *}$ & $0.766^{* * *}$ & $0,319^{*}$ & $0.517^{* * *}$ & $0.476^{* * *}$ & $0.579^{* * *}$ & $0.649^{* * *}$ & $0.626^{* * *}$ & $0.688^{* * *}$ & \\
\hline
\end{tabular}

$D O$, dissolved oxygen; $T N$, total nitrogen; $D N$, dissolved nitrogen; $T-P N$, total particular nitrogen; TOC, total organic carbon; DOC, dissolved organic carbon; T-POC, total particular organic carbon; TBA, total bacterial abundance; SRB, sulphate-reducing bacteria; $\left.{ }^{*} P<0.05 ;{ }^{* *} P<0.01\right) ;{ }^{* * *} P<0.001$. 
from both sites were characterized by lower TBA and lower counts of SRB, rods, bacilli, cocci and spiral-shaped bacteria which were determined at, $12.37 \pm 6.77 \times 10^{6}$, $1.53 \pm 0.96 \times 10^{6}, \quad 5.99 \pm 3.75 \times 10^{6}, \quad 5.01 \pm 2.60 \times 10^{6}, \quad 0.91 \pm$ $0.77 \times 10^{6}$ and $0.19 \pm 0.11 \times 10^{6}$ cells $\mathrm{mL}^{-1}$ respectively, in PO samples. In water samples from site $\mathrm{AC}, \mathrm{TBA}$ and the counts of SRB as well as rod- and spiral-shaped bacteria were several-times lower, and the maximum values of those parameters did not exceed $10.5 \times 10^{6}, 0.42 \times 10^{6}, 2.5 \times 10^{6}$ and $0.15 \times 10^{6}$ cells $\mathrm{mL}^{-1}$, respectively. Cocci and bacilli counts were similar to those noted in PO samples. In 2012, the highest values of TBA and counts of SRB, bacterial rods, cocci, bacilli and spiral-shaped bacteria were noted in $\mathrm{PO}$ samples at $22.08 \pm 7.86 \times 10^{6}, 7.51 \pm 1.52 \times 10^{6}, 11.77 \pm 5.12 \times$
$10^{6}, 6.01 \pm 3.06 \times 10^{6}, 1.06 \pm 0.59 \times 10^{6}$ and $2.98 \pm 1.31 \times 10^{6}$ cells $\mathrm{mL}^{-1}$, respectively. In samples from site AC, TBA values and the counts of SRB, rod- and spiral-shaped bacteria decreased several-fold in 2012 relative to PO samples. In samples from site PO, similar changes in the abundance of most analysed bacteria were observed throughout the study (Fig. 6a). Maximum values of TBA, and counts of SRB as well as rod- and spiral-shaped bacteria were noted at the beginning of summer stagnation and in early lake turnover in fall. The size of the above bacterial populations in $\mathrm{PO}$ samples varied significantly $(\mathrm{P}<0.001)$ with changes in ambient odour intensity and concentrations of $\mathrm{H}_{2} \mathrm{~S}, \mathrm{NH}_{4}-\mathrm{N}$, TN, DN, TOC and DOC. Negative correlations $(\mathrm{P}<0.001)$ were determined between TBA, counts of rod- and spiral-
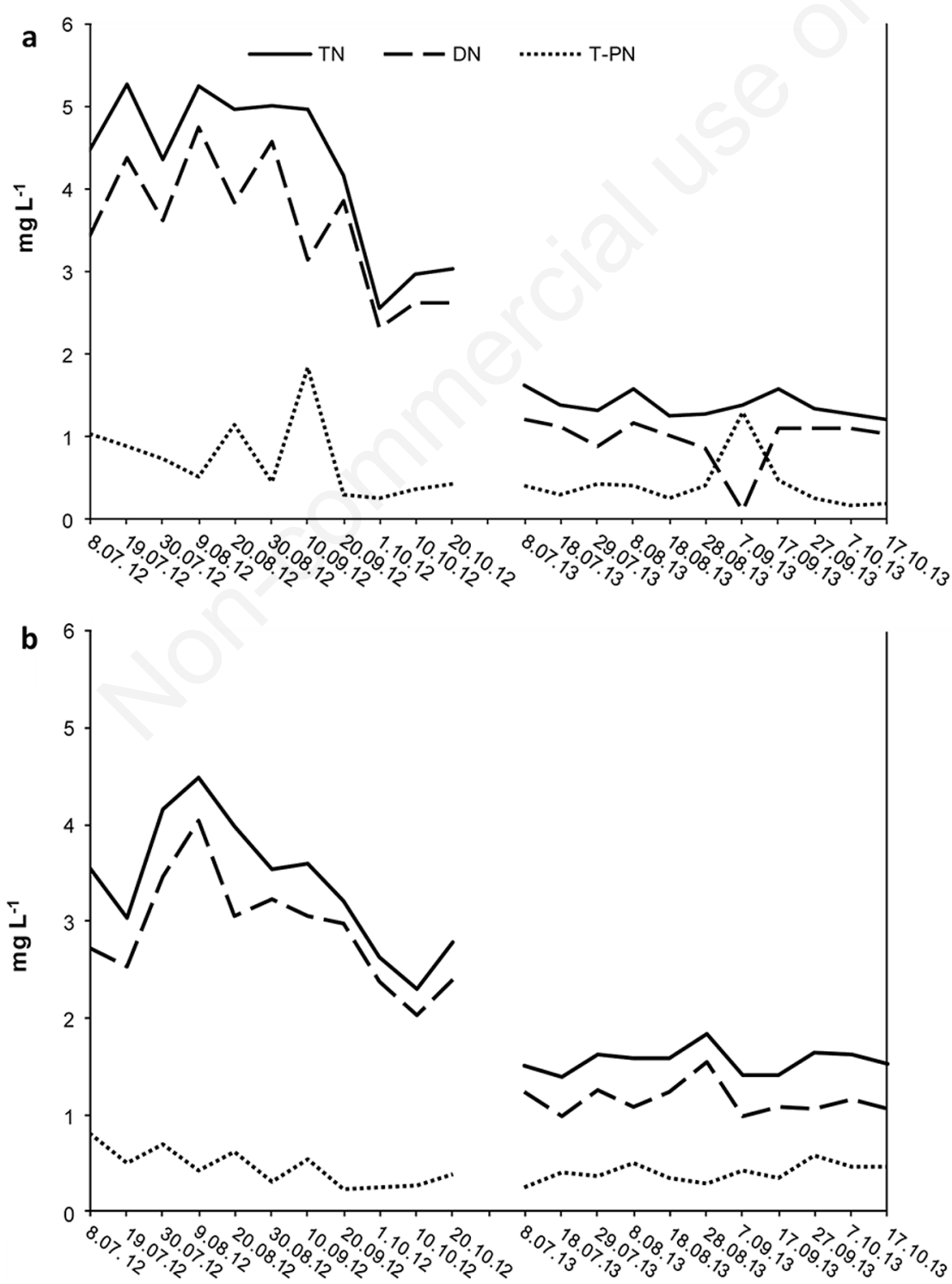

Fig. 4. Changes in the concentrations of TN, DN and T-PN in water samples collected from sites PO (a) and AC (b) in 2012 and 2013. 
shaped bacteria vs. $\mathrm{SO}_{4}$ and $\mathrm{DO}$ concentrations, whereas positive correlations $(\mathrm{P}<0.05)$ were noted between SRB and $\mathrm{SO}_{4}$ as well as between cocci counts and DO levels (Tab. 2). In AC samples, TBA and the counts of SRB, cocci and bacterial rods increased at the peak of summer stagnation in both years of the study. The populations of all analysed bacterial groups, excluding cocci, decreased at the beginning of fall turnover (Fig. 6b).

\section{Relationships between environmental drivers and bacterial community}

The multiple regression analysis confirmed the presence of significant correlations between TBA, counts of SRB, rod- and spiral-shaped bacteria vs. various forms of carbon and nitrogen only in PO samples. Total bacterial abundance and rod counts were determined by T-POC ( $\mathrm{r}=0.7052$, $\mathrm{P}<0.00022)$ and T-PN $(\mathrm{r}=0.7918, \mathrm{P}<0.00005)$, whereas the populations of spiral-shaped bacteria were correlated with TOC and $\mathrm{NH}_{4}-\mathrm{N}$ values $(\mathrm{r}=0.7581, \mathrm{P}<0.00001)$. The counts of SRB and rods correlated with $\mathrm{H}_{2} \mathrm{~S}(\mathrm{r}=0.9312, \mathrm{P}<0.9035)$, $\mathrm{TN}$ and $\mathrm{NH}_{4}-\mathrm{N}(\mathrm{r}=0.8765, \mathrm{P}<0.0474)$.

Differences in the percentage shape of SRB and morphology of bacterial populations were observed between years and sampling sites (Fig. 7). Water samples from site PO contained mostly and bacterial rods that accounted for $53 \pm 8 \%$ of TBA in 2012 and $47 \pm 8 \%$ of TBA in 2013. In the first year of the study, the percentage proportions of SRB,
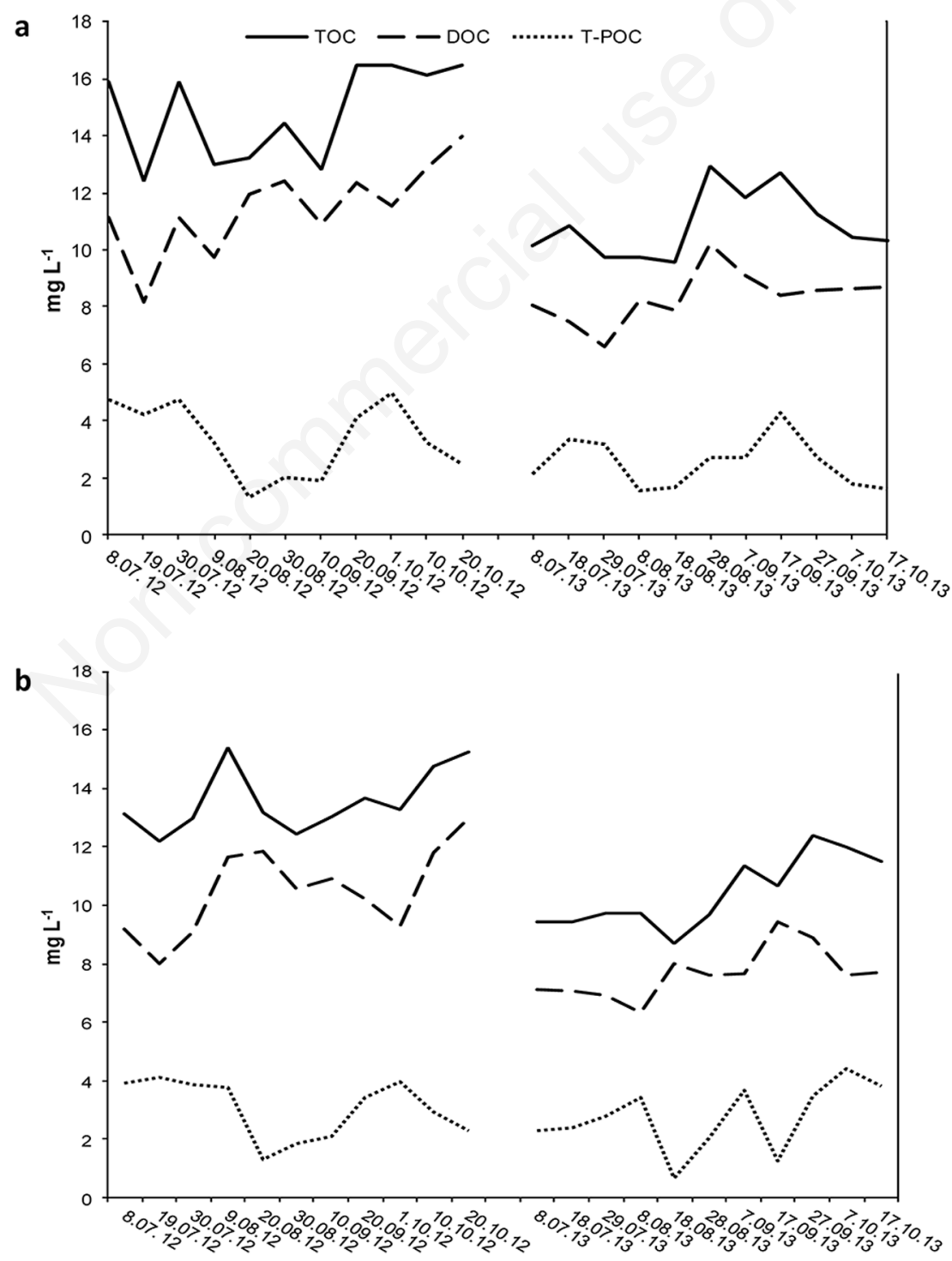

Fig. 5. Changes in the concentrations of TOC, DOC, and T-POC in water samples collected from sites PO (a) and AC (b) in 2012 and 2013. 
cocci, bacilli and spiral-shaped bacteria were determined at $34 \pm 9 \%, 27 \pm 7 \%, 5 \pm 3 \%$ and $15 \pm 5 \%$, respectively. In 2013 , the percentage of cocci increased to $43 \pm 8 \%$, whereas the share of SRB and spiral forms decreased to $12 \pm 5 \%$ and $2 \pm 3 \%$, respectively in PO samples. Water samples from site AC contained mostly cocci that accounted for $64-65 \pm 10 \%$ of TBA in 2012 and 2013. The proportions of rods $(24 \pm 6 \%$ in 2012 and $25 \pm 8 \%$ in 2013 ), bacilli ( $8 \pm 4 \%$ and $7 \pm 3 \%$ ), SRB $(7 \pm 4 \%$ in 2012 and $3 \pm 1 \%$ in 2013$)$, and spiral-shaped bacteria ( $4 \pm 2 \%$ and $3 \pm 2 \%$ ) in TBA were similar in both years of the study.

\section{DISCUSSION}

In the world literature the question of restoration of water is usually widely examined in terms of benefits to the water reservoir (Nürnberg, 2007; Dunalska et al., 2013; Zamparas and Zacharias, 2014). Simultaneously, there is a lack of detailed data on the negative effects of the use of such methods on the surrounding natural environment (water, atmospheric air) and organisms inhabiting them. This concerns in particular toxic substances such as hydrogen sulphide or ammonia, which are often released from the water to the air.

This process influences the formation of the characteristic odour, which may be a nuisance for the environment (Nürnberg, 2007; Brudniak et al., 2013). The problems of odours associated with the hypolimnetic withdrawal will probably be up to date in case of most of

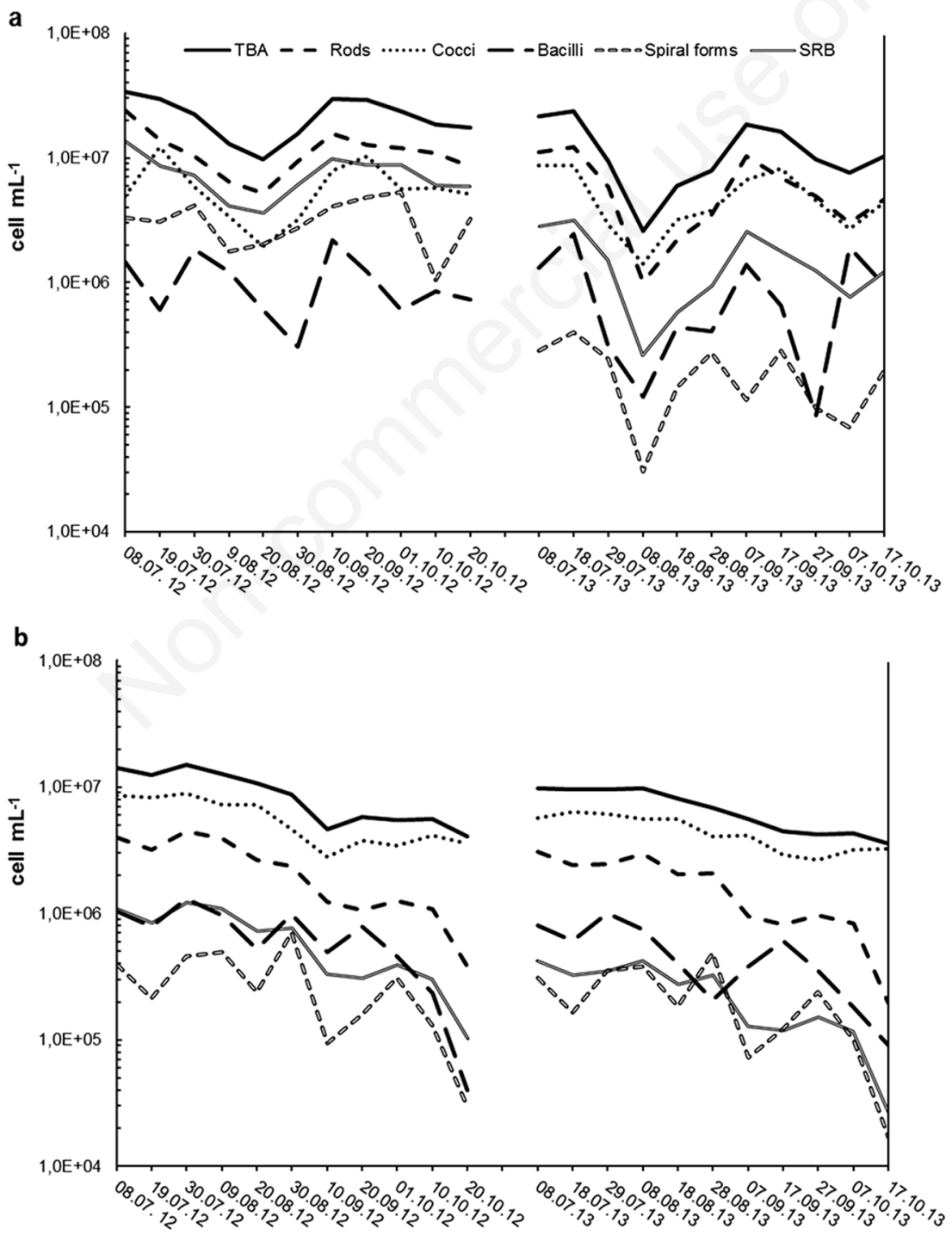

Fig. 6. Changes in TBA, numbers of rods, cocci, bacilli, spiral forms, and sulphate-reducing bacteria (SRB) in water samples collected from sites PO (a) and AC (b) in 2012 and 2013. 
the lakes restored in this method, regardless of their geographical location.

Summer odour emissions from Lake Kortowskie have continued for many decades. The local inhabitants and recreational lake users are aware that odour is a natural part of restorative processes in the lake, nonetheless, the emissions are a source of annoyance for members of the community and tourists. Organoleptic analyses produce valuable data, but they are subjective and difficult to standardize (Thornton and McMillan, 1989). Detectable odours are generally mixtures of many aroma compounds, including ammonia $\left(\mathrm{NH}_{3}\right)$, hydrogen sulphide $\left(\mathrm{H}_{2} \mathrm{~S}\right)$, sulphur dioxide $\left(\mathrm{SO}_{2}\right)$, carbon disulphide $\left(\mathrm{CS}_{2}\right)$, nitrobenzene $\left(\mathrm{C}_{6} \mathrm{H}_{5} \mathrm{NO}_{2}\right)$, aniline $\left(\mathrm{C}_{6} \mathrm{H}_{5} \mathrm{NH}_{2}\right)$, dimethylamine $\left(\mathrm{C}_{2} \mathrm{H}_{7} \mathrm{~N}\right)$ and formaldehyde (HCHO) (Wan et al., 2014). In ambient air, aroma compounds can occur in various concentrations, and they can produce different interactions. An aroma compound is generally impossible to identify in the presence of a more odorous substance (Wnorowski, 1992). Qualitative and quantitative combinations of aroma compounds can enhance, weaken or completely eliminate an olfactory sensation. For this reason, quantitative analyses of ambient air should rely on sensory methods that guarantee the objectiveness, repeatability and replicability of results (Gostelow et al., 2001; Kośmider et al., 2002).

The results of this study revealed that the intensity of ambient odour was correlated with the analysed physicochemical and microbiological parameters of water in the Kortówka River. Similarities were observed in the evalu-

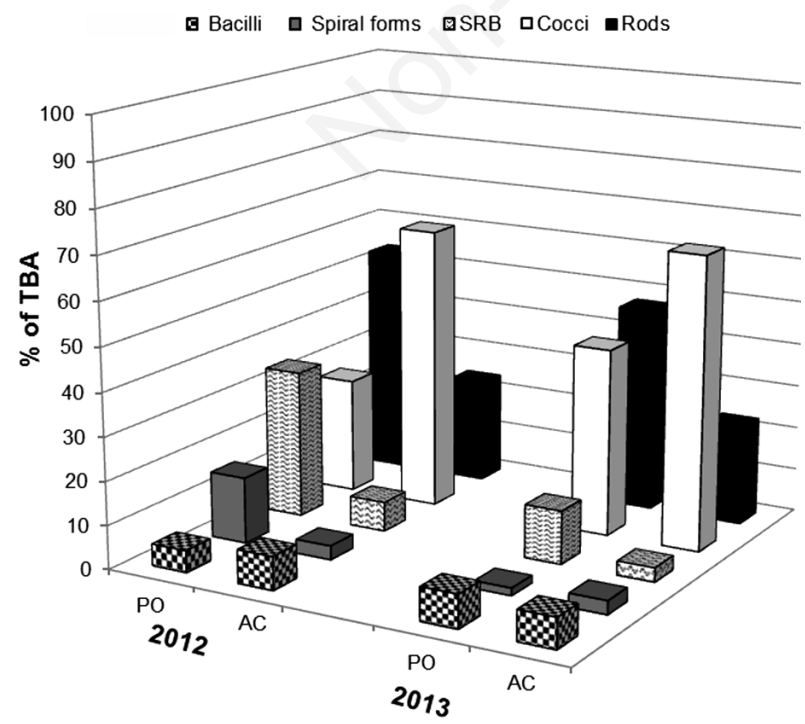

Fig. 7. Average percentages of rods, cocci, bacilli, spiral forms, and sulphate-reducing bacteria (SRB) in water samples collected from sites PO and AC in 2012 and 2013. ated parameters, their mutual correlations and the significance of differences between years and sampling sites. Ambient odour was directly correlated with TOC and DN values which were influenced by $\mathrm{H}_{2} \mathrm{~S}$ and $\mathrm{NH}_{4}-\mathrm{N}$ concentrations only at the outlet of the pipeline evacuating lake water to the river (PO). Hydrogen sulphide gives water a characteristic and unpleasant odour already at concentrations equal to hundredths of a milligram per 1 litre. The compound's odour changes when it is transported to ambient air by movement of water and difference in pressure (Brudniak et al., 2013). According to Hermanowicz et al. (1999) and Huu Huan et al. (2013), the threshold of $\mathrm{H}_{2} \mathrm{~S}$ detectability in air ranges between 0.0007 and $0.2 \mathrm{mg} \mathrm{L}^{-1}$. The fluctuations in odour intensity and the analysed physicochemical and microbiological parameters between the years of the study could be attributed to differences in the volume of water evacuated from the lake hypolimnion to the river. The amount of water discharged to the river was approximately $10-15 \%$ higher in 2012 than in 2013. The differences in the amount of water evacuated from the lake in each year of the study were not statistically significant, but the Spearman rank correlation analysis revealed significant correlations between the percentage of hypolimnetic water in river water and the majority of the examined physicochemical parameters (Tab. 2). The above implies that in 2012, intensified flow of lake water into the river could be responsible for higher pollution, including gaseous, in water samples collected from site PO. Those processes probably increased the intensity of ambient odour and the concentrations of all analysed parameters, excluding $\mathrm{DO}$ and $\mathrm{SO}_{4}$, in sampling site $\mathrm{PO}$. Throughout the experiment, ambient odour was minimized or completely eliminated at lower concentrations of $\mathrm{H}_{2} \mathrm{~S}, \mathrm{NH}_{4}-\mathrm{N}, \mathrm{TN}, \mathrm{DN}, \mathrm{TOC}, \mathrm{DOC}$, lower TBA and lower counts of SRB, rod- and spiral-shaped bacteria in AC samples collected at a distance of approximately 0.5 $\mathrm{km}$ from the outlet of the pipeline discharging lake water to the river (PO). Intensified odour of ambient air sampled from site $\mathrm{PO}$ was accompanied by higher values of parameters describing water samples drawn from the same site. The above was confirmed by the Spearman rank correlation analysis which demonstrated that odour intensity was correlated with $\mathrm{H}_{2} \mathrm{~S}$ levels $(\mathrm{r}=0.946 ; \mathrm{P}<0.001)$.

Hydrogen sulphide is a toxic gas which is produced in the hypolimnion by decomposing sulphur-containing organic matter or by dissimilatory sulphate reduction (Ito et al., 2002). The above processes take place in anaerobic conditions and in the presence of organic substances which supply hydrogen for sulphate reduction, such as organic acids and alcohols. In water bodies, the most supportive conditions for microbial sulphate reduction exist in bottom deposits and the oxygen-deficient hypolimnion (Zinder and Brock, 1978; Reis et al., 1992; Tandyrak and Lizuraj, 2008; Huu Huan et al., 2013). 
Bacteria from deep lake strata could be evacuated by the pipeline with $\mathrm{H}_{2} \mathrm{~S}$ and other pollutants, which created a supportive environment for microbial growth in PO. According to Muylaert et al. (2002), the morphology and quality of bacterial populations are largely determined by the specific trophic relationships between dissolved organic matter (bottom-up), heterotrophic bacteria and bacterivorous protozoa (top-down). Those mechanisms regulate the size and morphological structure of heterotrophic bacterial populations, and they are influenced by eutrophication and the depth of a water body. Water from the hypolimnion of Lake Kortowskie accounted for $40-50 \%$ of water in site PO. Oikonomou et al. (2014) demonstrated that the majority of bacterivorous protozoa are anaerobic organisms that play a limited role in the elimination of bacteria in oxygendeficient aquatic habitats. The above suggests that in our study organic matter (TOC, T-PN) supplied with hypolimnion water was the key factor responsible for the increase in TBA and counts of SRB, rod and spiral-shaped bacteria in PO. Those observations were confirmed by the results of multiple regression analysis. An indirect relationship between the counts of the analysed bacteria $v s \mathrm{H}_{2} \mathrm{~S}$ concentrations and odour intensity points to higher metabolic activity of microorganisms, in particular sulphate-reducing bacteria. Sulphate-reducing bacteria are morphologically diverse, and they include cocci, rods, spiral-shaped bacteria, cell aggregates (sarcina-like) and multicellular gliding filaments (Rabus et al., 2001). Those microorganisms oxidized simple organic compounds and reduced $\mathrm{SO}_{4}$ to $\mathrm{H}_{2} \mathrm{~S}$. In natural habitats, the production of $\mathrm{H}_{2} \mathrm{~S}$ is often indicative of the activity and presence of SRB (Babu et al., 2014). As a result of SRB metabolism, sulphur-reduced compounds can deteriorate the organoleptic properties of water, which leads to the emission of unpleasant odour (Wargin et al., 2007). The activity of SRB increased $\mathrm{H}_{2} \mathrm{~S}$ concentrations and odour intensity in water and air samples from PO after 10-20 days (Fig. 3a). Total bacterial abundance and the counts of SRB, rod- and spiral-shaped bacteria were positively correlated with $\mathrm{H}_{2} \mathrm{~S}$ levels and negatively correlated with DO concentrations. In site $\mathrm{AC}$, an increase in cocci counts was accompanied by an increase in DO levels and a drop in $\mathrm{H}_{2} \mathrm{~S}$ concentrations, and the above correlations were statistically significant at $\mathrm{P}<0.05$.

In our study, a significant correlation $(\mathrm{P}<0.05)$ was also noted between the intensity of ambient odour and $\mathrm{NH}_{4}-\mathrm{N}$ concentrations in water (Tab. 2). Similar results were reported by Wan et al. (2014) in Chinese rivers used for recreational purposes and by Yongsiri et al. (2004). In the group of aroma compounds studied by the above authors, $\mathrm{NH}_{4}-\mathrm{N}$ was the major substance responsible for odour emissions from water. The cited authors described $\mathrm{NH}_{4}-\mathrm{N}_{\text {and }} \mathrm{H}_{2} \mathrm{~S}$ as the key indicators in odour analyses. Similar trends were observed in our study where odour intensity changed with the concentrations of $\mathrm{H}_{2} \mathrm{~S}$ and $\mathrm{NH}_{4}-\mathrm{N}$ (Fig. 3a), and both compounds were correlated at a significance level of $\mathrm{P}<0.01$ (Tab. 2). The concentrations of this form of nitrogen in the analysed water samples were significantly correlated with TBA and the counts of SRB, rod- and spiral-shaped bacteria $(\mathrm{P}<0.001)$. The increase in $\mathrm{NH}_{4}-\mathrm{N}$ and T-PN values in water samples from PO, observed 10-20 days after the peak in bacterial counts, points to feedback between aquatic microbiota and the presence and availability of different forms of nitrogen. Gołaś et al. (2008) reported similar correlations between microorganisms breaking down nitrogen compounds in the Drwęca River, a receptacle of contaminated water from a fish farm. High nitrogen concentrations promoted microbial growth, therefore, the size of bacterial populations feeding on organic compounds in wastewater could be expected to be very high. Ammonia oxidation has a very high demand for oxygen, therefore, a decrease in DO concentrations lowers the rate of nitrification in a water body (Ruiz et al., 2006). The above inhibits self-purification of surface water by decreasing the rate of nitrificationdenitrification processes in a river (Yang et al., 2007).

In our study, the morphological structure of TBA and percentage share of SRB in the Kortówka River varied between the years of the study and sampling sites (Fig. 7). Water samples from site PO were colonized mainly by rodshaped bacteria (47-53 $\pm 8 \%$ TBA) and SRB (12-34 $\pm 6 \%$ ), whereas samples from site $\mathrm{AC}$ showed a predominance of cocci (64-65 $\pm 10 \%$ TBA). The differences in the proportions of rods, SRB and cocci between sampling sites could be attributed to the stimulating influence of organic substances on rod-shaped bacteria and SRB, as indicated by increased values of the analysed chemical parameters and higher counts of rods, SRB and cocci in site PO than in AC. The above is also validated by statistically significant correlations between bacterial counts and the concentrations of various forms of carbon, nitrogen and $\mathrm{H}_{2} \mathrm{~S}$ (Tab. 2). Similar results were reported by Bertoni et al. (2010) in an analysis of correlations between epilimnetic and hypolimnetic bacteria and organic carbon in the deep holo-oligomictic Lake Maggiore. In our study, in water samples from site PO in 2012, SRB and spiral-shaped bacteria accounted for $34 \%$ and $15 \%$ of TBA, respectively, and their counts were highly significantly correlated $(\mathrm{P}<0.01, \mathrm{P}<0.001)$ with the concentrations of $\mathrm{H}_{2} \mathrm{~S}$, various forms of nitrogen $\left(\mathrm{NH}_{4}-\mathrm{N}, \mathrm{TN}, \mathrm{PN}, \mathrm{T}-\mathrm{PN}\right)$ and DOC. The above created a supportive environment for rods and spiral-shaped of sulphate-reducing bacteria (SRB). Under anaerobic conditions, dissimilatory SRB use sulphate as a terminal electron acceptor in the degradation of organic matter, which leads to the production of $\mathrm{H}_{2} \mathrm{~S}$. The second source of $\mathrm{H}_{2} \mathrm{~S}$ is organic matter decomposed by morphologically varied heterotrophic bacteria that are become pleomorphic in response to environmental changes (Young, 2006). $\mathrm{H}_{2} \mathrm{~S}$ is a highly reactive, corrosive and 
toxic compound which causes numerous environmental problems (Hulshoff-Pol et al., 1998; Shabir et al., 2007). In water samples from site $\mathrm{AC}$, cocci were the predominant bacteria, and cocci counts were not significantly correlated with the physicochemical parameters of water, except DO. Similar results were reported by Feng and Duan (2011) in the eutrophic Lake Taihu in China.

In this study, the variations in the proportions of SRB, bacterial rods, cocci and spiral forms between sampling sites $\mathrm{PO}$ and $\mathrm{AC}$ indicate that the physicochemical parameters of water significantly influence the abundance and morphological structure of bacterial populations. The presence of statistically significant correlations between bacterial counts, the hydrochemical parameters of water and the intensity of ambient odour indicates that studies of the type contribute to health protection, minimize the risk of environmental pollution and create optimal conditions for recreation.

\section{CONCLUSIONS}

The results of our study into the quality of ambient air and water in the Kortówka River indicate that hypolimnetic withdrawal, a lake restoration method, directly contributes to the production of a detectable odour in the vicinity of the restored water body. In this study, odour intensity varied subject to the distance from the pipeline outlet and the quantity of hypolimnetic water discharged to the river. In 2012, more water was evacuated to the river than in 2013, which contributed to intensified transfer of organic matter and gases from oxygen-deficient deep strata of the lake to the ecosystem of the Kortówka River. The above increased TOC concentrations, TBA values $(r=0.7052)$ and the counts of rod-shaped $(r=0.7918)$ and spiral-shaped bacteria $(\mathrm{r}=0.7581)$ in sampling site $\mathrm{PO}$. Higher abundance and, probably, metabolic activity of those bacteria especially of SRB group increased $\mathrm{H}_{2} \mathrm{~S}$ $(\mathrm{r}=0.9312)$ and $\mathrm{NH}_{4}-\mathrm{N}(\mathrm{r}=0.8765)$ levels in water samples from site PO. The concentrations of those compounds were highly significantly $(\mathrm{P}<0.001)$ or significantly $(\mathrm{P}<0.05)$ correlated with the intensity of ambient odour.

As our research showed the level of odour in the atmosphere depended on the quality of water discharged from hypolimnion. This suggests that this phenomenon was closely related to the restoration method of the lake. Therefore, we think that this issue should be taken into account in cases where the use of this method in other places worldwide.

\section{ACKNOWLEDGMENTS}

We wanted to thank the panellists for their work with odour determination: Karolina Babul, Katarzyna Portalska and Jakub Kowalczyk. This study was supported by grants No 18.610.007-300 and 528-0807-0806 from the Ministry of Science and Higher Education (Poland).

\section{REFERENCES}

Amann RI, Binder BJ, Olsen RJ, Chisholm SW, Devereux R, Stahl DA, 1990. Combination of 16S rRNA-targeted oligonucleotide probes with flow cytometry for analyzing mixed microbial populations. Appl. Environ. Microbiol. 56:1919-1925.

Azkona A, Jenkins SH, Roberts HMG, 1984. Sources of pollution of the estuary of the River Nervion, Spain - a case study. Water Sci. Technol. 16(5-7):95-125.

Babu GP, Subramanyam P, Sreenivasulu B, Paramageetham Ch, 2014. Isolation and identification of sulfate reducing bacterial strains indigenous to sulphur rich barite mines. Int J Curr Microbiol App Sci 3(7):788-793

Bajkiewicz-Grabowska E, Magnuszewski A, Mikulski Z, 1987. General hydrology-class guide. [in Polish]. PWN: 196 pp.

Bertoni R, Callieri C, Corno G, Rasconi S, Caravati E, Contesini M, 2010. Long-term trends of epilimnetic and hypolimnetic bacteria and organic carbon in a deep holo-oligomictic lake. Hydrobiologia 644 (1):279-287.

Brudniak A, Dębowski M, Zieliński M, 2013. Odour nuisance accompanying hypolimnetic withdrawal method on the example of the Kortowskie Lake. Ecological Chemistry and Engineering A 20:4-5.

Cooke GD, Heath RT, Kennedy RH, McComas MR, 1982. Change in trophic state and internal phosphorus release after aluminium sulphate application. Water Resour. Bull. 18(4): 699-705.

Cooke GD, Welch EB, Peterson SA, Newroth PR, 1993. Restoration and management of lakes and reservoirs. Lewis Pub. (CRC Press, Inc.), Boca Raton, FL.

Dunalska J, 2003. Impact of limited water flow in a pipeline on the thermal and oxygen conditions in a lake restored by hypolimnetic withdrawal method. Pol. J. Environ. Stud. 12(4): 409-416.

Dunalska J, Wiśniewski G, Mientki Cz, 2007. Assessment of multi-year (1956-2003) hypolimnetic withdrawal from Lake Kortowskie, Poland. Lake Reserv. Manage. 23: 377-387.

Dunalska JA, Górniak D, Jaworska B, Evelyn E, Gaiser EE, 2012. Effect of temperature on organic matter transformation in a different ambient nutrient availability. Ecol. Eng. 49:27-34.

Dunalska JA, Oszczak B, Tanajewski D, Gomułka P, 2013. Effect of increased hypolimnion water temperature on stability of thermal profiles in stratified lakes. AWER Procedia Adv. Appl. Sci. 1: 632-636.

Elloumi J, Guermazi W, Ayadi H, Bouaïn A, Aleya L, 2008. Detection of water and sediments pollution of an Arid Saltern (Sfax, Tunisia) by coupling the distribution of microorganisms with hydrocarbous. Water Air Soil Poll. 187:157-171. EN 13725:2003: Air quality - Determination of odour concentration by dynamic olfaktometry. Available from: http://www.en-standard.eu/

Feng S, Duan X-M, 2011. Changing of microbial community in a large eutrophicatied shallow lake. Procedia Environ. Sci. 10:1416-1424.

Gołaś I, Zmysłowska I, Harnisz M, Korzekwa K, Skowrońska A, Teodorowicz M, Górniak D, Gros M, Brzozowa S, 2008. Nitrogen cycle bacteria in the waters of the Drwęca River. Pol. J Environ. Stud. 17(2):215-225.

Gostelow P, Parsons SA, Stuetz RM, 2001. Odour measurements for sewage treatment works. Water Res. 35:579-597.

Gotkowska-Płachta A, Gołaś I, Korzeniewska E, Koc J, Rochw- 
erger A, Solarski K, 2016. Evaluation of the distribution of faecal indicator bacteria in a river system depending on different types of land use in the southern watershed of the Baltic Sea. Environ. Sci. Pollut. Res. 23:4073-4085.

Górniak D, Tandyrak R, Parszuto K, Misiun J, 2014. Relationships between physico-chemical and microbiological parameters in the monimolimnion of a forest meromictic lake. J. Limnol. 73:511-522.

Hermanowicz W, Dożańska W, Dojlido J, Koziorowski B, 1999. [Fizyczno-chemiczne badanie wody i ścieków].[Book in Polish]. Arkady, Warszawa: 556 pp.

Hiremath PS, Bannigidad P, 2012. Spiral bacterial cell image analysis using active contour method. Int. J. Comput. Appl. 37(8):5-9.

Hulshoff-Pol LW, Lens PN, Stams AJ, Lettinga G, 1998. Anaerobic treatment of sulphate-rich wastewaters. Biodegradation 9:213-224.

Huu Huan N, Xuan Hai N, Yem T, Nhan Tuan N, 2013. Factors effect to the sulfide generation rate in the To Lich River, Vietnam. ARPN J. Eng. Appl. Sci. 8:190-199.

Ito T, Okabe S, Satoh H, Watanabe Y, 2002. Successional development of sulfate-reducing bacterial populations and their activities in a wastewater biofilm growing under microaerophilic conditios. Appl. Environ. Microbiol. 68:1392-1402.

Klapper H, 1991. Control of eutrophication in inland waters. Ellis Horwood, New York: 337 pp.

Kośmider J, Mazur-Chrzanowska B, Wyszyński B, 2002. [Odory].[Book in Polish]. Warszawa PWN: 300 pp.

Lehman EM, McDonald KE, Lehman JT, 2009. Whole lake selective withdrawal experiment to control harmful cyanobacteria in an urban impoundment. Water Res. 43:1187-1198.

Loy A, Maixner F, Wagner, M, Horn M, 2007. ProbeBase - an online resource for rRNA-targeted 474 oligonucleotide probes: new features 2007. Nucleic Acids Res. 3:800-804.

Manz W, Eisenbrecher M, Neu TR, Szewzyk U, 1998. Abundance and spatial organization of Gram-negative sulfate reducing bacteria in activated sludge investigated by in situ probing with specific 16S rRNA targeted oligonucleotides. FEMS Microbiol. Ecol. 25:43-61.

Marshall DW, Otto M, Panuska JC, Jaeger SR, Sefton D, Baumberger TR, 2006. Effects of hypolimnetic releases on two impoundments and their receiving streams in southwest Wisconsin. Lake Reserv. Manage. 22:223-232.

Muylaert K, Van der Gucht K, Vloemans N, De Meester L, Gillis M, Vyverman W, 2002. Relationship between bacterial community composition and bottom-up versus top-down variables in four eutrophic shallow lakes Koenraad. Appl. Environ. Microb. 68:4740-4750.

Nürnberg GK, 2007. Lake responses to long-term hypolimnetic withdrawal treatments. Lake Reserv. Manage. 23:300-409.

Oikonomou A, Pachiadaki M, Stoeck T, 2014. Protistan grazing in a meromictic freshwater lake with anoxic bottom water. FEMS Microbiol Ecol. 87:691-703.

PN-EN 1484:1999. Water analysis. Guidelines for determining the concentrations of total organic carbon (TOC) and dissolved organic carbon. [in Polish]. Available from: http://sklep.pkn.pl/pn-en-1484-1999p.html

Porter KG, Feig YS, 1980. The use of DAPI for identifying and counting aquatic microflora. Limnol. Oceanogr. 25:943-948.

Rabus R, Fukui M, Wilkes H, Widdel F, 1996. Degradative capacities and 16S rRNA-targeted whole-cell hybridization of sulfate-reducing bacteria in an anaerobic enrichment culture utilizing alkylbenzenes from crude oil. Appl. Environ. Microbiol. 62:3605-3613.

Rabus R, Hansen T, Widdel F, 2001. Dissimilatory sulfate- and sulfur-reducing prokaryotes, p. 659-768. In: M. Dworkin, S. Falkow S, E. Rosenberg, K-H. Schleifer and E. Stackebrandt (eds.), The prokaryotes. 3rd ed. Springer-Verlag, New York.

Reis MAM , Almeida JS, Lemos PC, Carrondo MJT, 1992. Effect of hydrogen sulfide on growth of sulfate reducing bacteria. Biotechnol. Bioeng. 40:593-600.

Ruiz G, Jeison D, Rubilar O, Ciudad G, Chamy R, 2006. Nitrification-denitrification via nitrite accumulation for nitrogen removal from wastewaters. Bioresource Technol. 97:330-335.

Ruusuvuori P, Seppälä J, Erkkilä T, Lehmussola A, Puhakka J, Yli-Harja O, 2008. Efficient automated method for imagebased classification of microbial cells. Proc. 19th Int. Conf. on Pattern Recognition, ICPR 2008, Tampa, FL, USA, 7-11 December 2008: 4 pp.

Shabir A, Dar Li Y, Udo van Dongen J, Kuenen G, Muyzer G, 2007. Analysis of diversity and activity of sulfate-reducing bacterial communities in sulfidogenic bioreactors using $16 \mathrm{~S}$ rRNA and dsrB genes as molecular markers. Appl. Environ. Microb. 73:594-604.

Stanisz A, 2006. [Przystępny kurs statystyki z zas-tosowaniem STATISTICA PL na przykładach z medycyny. Tom 1 . Statystyki podstawowea].[Book in Polish]. StatSoft Poland, Cracow: 532 pp.

Tandyrak R, Lizuraj M, 2008. Multiannual observations of iron and sulphur content in the waters of recultivated Lake Starodworskie waters, with comparison to selected physical and chemical parameters. Limnol. Rev. 8:129-136.

Tonolla M, Demarta A, Peduzzi S, Hahn D, Peduzzi R, 2000. In situ analysis of sulfate-reducing bacteria related to Desulfocapsa thiozymogenes in the chemocline of meromictic Lake Cadagno (Switzerland). Appl. Environ. Microbiol. 66:820-824.

Thornton JA, McMillan PH, 1989. Reconciling public opinion and water quality criteria in South Africa. Water SA 15:221-226.

Wan Y, Ruan X, Wang X, Ma Q, Lu X, 2014. Odour emission characteristics of 22 recreational rivers in Nanjing. Environ. Monit. Assess. 186:6061-6081.

Wargin A, Olańczuk-Neyman K, Skucha M, 2007. Sulphate-reducing bacteria, their properties and methods of elimination from groundwater. Pol. J Environ. Stud. 16:639-644.

WHO, 2003. Hydrogen sulfide: human health aspects. Concise International Chemical Assessment Document 53, Geneva.

Wnorowski AU, 1992. Tastes and odours in the aquatic environment: a review. Water SA 18: 03-214.

Yang HJ, Shen ZM, Zhang P, Wang WH, 2007. Water quality characteristics along the course of the Huangpu River (China). J. Environ. Sci. 19:1193-1198.

Yongsiri C, Vollertsen J, Hvitved-Jacobsen T, 2004. Effect of temperature on air-water transfer of hydrogen sulfide. J. Environ. Eng. 130:104-109

Young, KD, 2006. The selective value of bacterial shape. Microbiol. Mol. Biol. Rev. 70:660-703.

Zamparas M, Zacharias I, 2014. Restoration of eutrophic freshwater by managing internal nutrient loads. A review. Sci. Total Environ. 496:551-562

Zinder SH, Brock TD, 1978. Methane, carbon dioxide, and hydrogen sulfide production from the terminal methiol group of methionine by anaerobic lake sediments. Appl. Environ. Microb. 35:344-352. 